Hughes or any individual who has acted like him, I hold with Shylock, that it is unwise to let a serpent "sting you twice." The man who can prostitute his tongue to pander to the malignity of his heart, will hardly hesitate to embody his venom into act.

So much by way of reply to the gravamen of the charge. However I can assure W. Hughes that his till has not sustained any serious loss by the want of my prescriptions. The charge for medicine taken by the patient, whom with infinite assurance he calls his, since I have prescribed for her amounts, I am told, to one shilling and mine pence. That such economy in medicine "is a fault" in his eyes, as well as in those of his genus $\dot{I}$ am well aware.

Since this person has coupled my name with that of Mr. St. John Long, I must distinctly state that I never saw that gentleman until the day it was decided by his legal advisers that $I$ should be summoned as a witness; and it is well known that sercral of the most eminent (men) in the profession entertained, and still entertain, opinions similar to my own with respect to the unmerited persecutions he underwent.* True, I was almost the only one who arowed such sentiments publickly; but as I did not then, so do I trust I never shall, shrink from giving utterance to my feelings. For the man himseif I conld have no regard. I was unacquainted with him. But science, and more than this a moral question of interest to our common humanity were both at stake; and I looked merely at them, uninfluenced by any envious feelings at the wealth Mr. St. John Long was said to be arnassing by his practice.

I hope that W. Hughes (I cannot debase the $M r$. by applying it to him) will understand once for all, that no prescription of mine shall ever, with my privity, be placed in his hands. A mistake 1 could forgive, a meanness pity; but 1 must remind him, that a falsehood calls up against its utterer the principle of selfdefence. We may indeed both forgive and pity; but must beware.

Feancis H. Ramadge, M.D.

"To Dr. Ramadge, \&.c. \&c. \&c.

"Sir,--llament much that the case of my servant sloult lave renewed any former unpleasanties between my medical attendant Mr. Hughes and Jourself. Allow me to state that the dictum adopted by the Medical Society towaras you in legard to yon conduet towards the late Mr. St. John Long, never will make any impres-

* We shall be very glad if Dr. Ramadge would mention the names of these "cminent" individuals.--E. L. sion to your disadvantage on me as to your professional skill in which opinion $I$ am not a singular instance. I am, sir, your obt. lible. servant, "34, Southampton-street, Strand, Mity 61h, 1835."

J. BнAIIAM

Mity 6th, 1835."

MR. H. W. DEWHURST.

To the Editor of The LANCET.

SrR,-As the article respecting me in Tre Lancet of May 9 th has done me a most serions injury in the profession, I must therefore solicit you, which I do most respectfully, to cause the insertion of this letter in your next number. In the autumn of 1831 , I was introduced to Dr. Brandreth by my excellent and our mutual friend Major-General Sir James Viney, G. C. B., at his residence in Piccadilly.* In January following (1832), in reply to a letter I received from him, I wrote him the one published in THe LANCET, but not with the remotest view of its being ever published. About four months ago, on secing it published in the Satirist Newspaper, I wrote to Mr. Hodgkinson, the grocer in Aldersgate Street, who purchased the prescription of the pills from Dr. Brandreth on his leaving England for New York, to desire that he would desist from publishing the letter bearing $m y$ name. This, however, he continues to do, and nothing but legal proceedings (which I cannot afford to institute) will prevent him and his agent, Mr. Lucas, the druggist, in the same street.

I know nothing of his bearing the name of Holmes, but I am aware of his brother-in-law having that name, who is a civil engineer, whom also I met at Sir James Viney's. As a proof of my upholding quackery, I refer you to my letter on medical elucation inserted in the Morning Advertiser of the 4 th of May ; and as a still further proof of niy not being so, I will give your readers the composition of "Brandreth's Universal Pills," sent to me by a friend who assisted him in their preparation for some time, and whom I can produce if necessary. A mass is formed of powdered gum gamboge, powdered ginger, powdered aloes, oil of cassia, and oil of peppermint, divided into three-grain pills. Conceiving these to form an excellent aperient medicine, I have taken them, as well as several members of my faruily, when occasion has required. I remain, yours, \&c. H. W. Dewhunst. May 15, 1835.

* We should be exceedingly glad to be made acquainted with the present place of residence of Major-General Sir Jamcs Viney, G.C.B.-ED, L. 
I situation at a moment when he was daily

A conRespondent residing at Woolwich, a medical practitioncr, has forwarded to us two cases for publication, in which citrine ointment and catechu were used with success for the following purposes.

Camphorated Citrine Ointaent in Hyonocene.-A few weels after a fall which occasioned an inguinal hernia, the right testicle, without any evident cause, began to swell, and became too painful to be handled. (The accident occurred to our correspondent.) This was soon followed by hydrocele, when the pain, which had by this time abated considerably, went off gradually, but the swelling secmed to be stationary. Meanwhile the hydrocele increased, and caused much suffering from tension of the scrotum. I consented to have the water lrawn off, but in the interval a different morle of treatment occurred to my mind. Haring frequently witnessed the bencficial effects of the citrine ointment (Unguentum Hydrargyri Nitratis) with camphor in cases of glandular and other indurated tumours, I thought it would also excite the torpid absorbents in those of an aqueous lind, and therefore preferred this trial to that of the knife. In applying it I grasped the left or sound side of the scrotum firmly, so as to make the tumour as tense as possible, and then rubbed a small quantity of the ointment (about 25 or 30 grains) over its surface for a due length of time. This $I$ repeated every evening as long as it was necessary, generally before a fire. After using the ointment for a week or ten days, the tumour was evidently diminished in bulk, and, persevering with it some time longer, the tumonr eventually disappeared. In the meantime there was little alteration in the swelling of the testicle, but as it gare me little or no pain, except when handled, I left it to its own vis medicatrix. and that was slow enough, as it was fully three months before it was reduced to the size of the other. The hydrocele has never returned in any way. The citrine ointment was made by afling a drachm of camphor to an ounce of the ointment.

Catechu in Mercurial Ptyalism.Capt. B., twenty-five years of age, having had occasion to undergo a short course of mercury, whilst his regiment was encamped near Harwich, during rather a cold summer, unexpectedly experienced, about the fifth day of the course, approaching ptyalism; and when. I was summoned to visit him in the evening, I found him in bed, spitting, of rather slavering, profusely, and presenting a picture of despair, from distress of mind, occasioned by his expecting a visit from a party of valued friends, most of them females, to the cainp. It was no easy matter to determine under these urgent circumstances what means to use. I had long ago proved the utter inefficiency of alum, opium, and other reputed antidotes against salivation, and at last I thought of catechu, of which I had made a strong decoction for some other purpose, though it was a remedy as yet untried, at least by me. To be brief, I desired my patient to take a wineglassful (about 3 ii to 3 iiss) of this decoction every two hours, or even oftener, if his stomach would bear it; and also to gargle his mouth and fauces as frequently as possible with the same. The result was, that when I visited him early on the next morning, the spitting had entirely censed, and every other sign of the effects of mercury had wholly disappeared, debility from the ptyalism alone excepted. I think that since this case occurred I have had further proof of the efficacy of catechu in obviating the ulrimate effects of mercury, and I invite your numerous readers to make trial of it in cases of mercurial ptyalism. Instead of 5 iiss of catechu to half a pint of boiling water, according to the London Pharmacopoia, I use at least $j^{\text {iij }}$ to that quantity of boiling water; for whether infusion or decoction be used, it ought to be made as strong as possible.

\section{CHARGE OF \\ UNPROFESSIONAL CONDUCT.}

\section{To the Editor of THE LANCET.}

Sir,-On the 13th of February last I was called at three p. $m$. to attend a female child fifteen months old, living in this place, who had been labouring under an attack of measles during three days. The case had been attended with the usual symptoms. The eruption was then dis. appearing, and the child evidently labour. ing under inflammation of the lungs; the bowels had been freely opened on that day. I immediately ordered a grain and a half of calomel, and two of James's powder, to be given with a tablespoonful of sudorific mixture. The powder was repeated on the following morning, and a third was given some time after. This was all the calomel the child took during my attendance. It complained of soreness of the mouth on the night that the first powder was administered. About the third day after, the mucous surface of the fauces recame sore and inflamed, occasioning great pain to the little patient, and an aversion from taling the breast, These 